\title{
Identification of Candidate Genes that Specifically Regulate Subcutaneous and Intramuscular Fat Deposition Using Transcriptomic and Proteomic Profiles in Dingyuan Pigs
}

\section{Pan Zhang}

China Agricultural University

Qinggang Li

Anhi Academy of Agricultural Sciences

Yijing Wu

Anhi Academy of Agricultural Sciences

\section{Yawen Zhang}

China Agricultural University

Bo Zhang ( $\sim$ bozhang0606@cau.edu.cn)

China Agricultural University

Hao Zhang

China Agricultural University

\section{Research Article}

Keywords: Sus scrofa, transcriptomics, tandem mass tags, subcutaneous fat, intramuscular fat, RNA-Seq

Posted Date: September 1st, 2021

DOI: https://doi.org/10.21203/rs.3.rs-754325/v2

License: (c) (i) This work is licensed under a Creative Commons Attribution 4.0 International License.

Read Full License 


\section{Abstract}

Background: Subcutaneous fat and intramuscular fat (IMF) deposition are closely related to meat production and pork quality. The Dingyuan pig is a local pig breed in Anhui Province, China, that has great potential for fat deposition. Individuals with extreme subcutaneous fat and intramuscular fat content can be found in this breed, which provides a good study system for investigating the molecular mechanisms regulating these two types of fat deposit.

Results: In this study, we used RNA-Seq and tandem mass tags-based proteomics to analyze the key pathways and genes that specifically regulate subcutaneous fat and intramuscular fat deposition in Dingyuan pigs. We identified 191 differentially expressed genes (DEGs) and 61 differentially abundant proteins (DAPs) in the high backfat thickness (HBF) and low backfat thickness (LBF) groups. In the high intramuscular fat and low intramuscular fat groups, we found 85 DEGs and 12 DAPs. The gene ontology and KEGG pathway enrichment analysis showed that the DEGs and DAPs in the backfat groups were mainly involved in various metabolic pathways, such as those related to carbohydrates, amino acids, esters, and fatty acids, whereas the DEGs and DAPs of the IMF groups were involved in a wide range of signaling pathways, including metabolic pathways, the insulin pathway, ketone body synthesis and degradation, longevity, and some disease-related pathways. Among the genes related to the metabolic pathways of carbohydrates, amino acids, esters, and fatty acids, we found 26 candidate genes that specifically regulate subcutaneous fat deposition and 7 genes that specifically regulate IMF deposition in Dingyuan pigs.

Conclusion: Our data show that subcutaneous fat deposition and IMF deposition are regulated by the same genes, but there are also genes that specifically regulate these two fat depositions. Our data provide insights into the mechanisms of pig fat deposition.

\section{Background}

China's pig breeds are rich in genetic resources and have good meat quality. However, they also suffer from problems such as a slow growth rate, high fat deposits, and low lean meat percentages [1]. Commercial pig breeds have improved lean meat percentages and reduced subcutaneous fat deposits; however, they simultaneously have low intramuscular fat content and poor meat quality [2-5]. Porcine subcutaneous fat is quantified by backfat thickness, which is negatively correlated with lean meat percentage and positively correlated with intramuscular fat [6]. The intramuscular fat (IMF) content plays a decisive role in the quality and flavor of pork [7]. Due to the positive genetic correlation between the two fat traits [8], increasing the intramuscular fat content while reducing the deposition of subcutaneous fat has always been a challenge in pig breeding.

The Dingyuan pig is an indigenous pig breed distributed in Dingyuan County, Anhui Province, China. It has the advantages of strong disease resistance, high intramuscular fat, and good meat quality, but also has a low lean meat percentage and relatively slow growth rate. The slaughter test of a large sample size 
of Dingyuan pigs revealed that some individuals had thinner subcutaneous fat even though their growth rate and IMF content were similar to those of other individuals. Therefore, we believe that this population may harbor key genes that specifically regulate subcutaneous and intramuscular fat deposition, providing a good study system to investigate the molecular mechanisms regulating tissue-level differences in fat deposition.

RNA sequencing (RNA-Seq) is a transcript quantification technology widely used to measure gene expression in tissues. Although RNA-Seq has been used to analyze the transcriptome profiles of subcutaneous and intramuscular fat in pigs, most of these studies have been conducted using different pig breeds $[9,10]$. Some researchers have used pigs of the same breed with different phenotypes to study the mechanism of subcutaneous or intramuscular fat deposition [6, 11]; however, there are few reports on the simultaneous study of subcutaneous and intramuscular fat. In this study, we used RNA-Seq to study gene expression in subcutaneous and intramuscular fat simultaneously. We also used proteome analysis technology based on tandem mass tags (TMT) because it has improved proteome coverage and more reliable peptide identification and quantification, which is suitable for analyzing thousands of proteins in complex biological samples [12]. Such integrated transcriptome and proteome analyses can provide insights into key functional genes and their regulatory mechanisms between different types of fat deposits in pigs.

In this study, we collected tissues of subcutaneous fat and the longissimus dorsi (LD) muscle from pigs of similar age and body weight with divergent backfat thickness and intramuscular fat content.

Transcriptomic and proteomic data were obtained using RNA-Seq and TMT to identify the key genes and pathways that specifically regulate subcutaneous fat and intramuscular fat deposition in Dingyuan pigs.

\section{Results}

\section{Summary of pig performance}

The phenotypic traits of the pigs used in this study are listed in Table 1. The backfat thickness and dressing percentage of the HBF group were significantly higher than those of the LBF group $(P<0.05)$. However, the body weight, intramuscular fat content, and lean meat percentage were not significantly different between the two groups $(P>0.05)$. The IMF content was significantly higher in the HIMF group than in the LIMF group $(P<0.05)$. 
Table 1

Phenotypic data at slaughter and meat quality of Dingyuan pigs. IMF, Intramuscular fat; LBF, low backfat thickness; HBF, high backfat thickness; HIMF, high intramuscular fat; LIMF, low intramuscular fat.

\begin{tabular}{|lllll|}
\hline Groups & HBF & LBF & HIMF & LIMF \\
\hline Weight $(\mathrm{kg})$ & $88.17 \pm 5.06^{\mathrm{a}}$ & $90.57 \pm 3.55^{\mathrm{a}}$ & $86.17 \pm 3.29^{\mathrm{a}}$ & $89.67 \pm 2.04^{\mathrm{a}}$ \\
\hline IMF $(\%)$ & $6.88 \pm 2.68^{\mathrm{a}}$ & $4.20 \pm 2.05^{\mathrm{a}}$ & $6.30 \pm 0.56^{\mathrm{a}}$ & $2.97 \pm 0.95^{\mathrm{c}}$ \\
\hline Backfat (thickness/cm) & $5.53 \pm 0.49^{\mathrm{a}}$ & $2.53 \pm 0.42^{\mathrm{c}}$ & $5.10 \pm 1.11^{\mathrm{a}}$ & $3.67 \pm 1.12^{\mathrm{a}}$ \\
\hline Dressing percentage & $78.33 \pm 0.01^{\mathrm{a}}$ & $72.33 \pm 0.01^{\mathrm{c}}$ & $78.10 \pm 2.13^{\mathrm{a}}$ & $74.53 \pm 3.17^{\mathrm{a}}$ \\
\hline Lean meat percentage & $46.01 \pm 5.03^{\mathrm{a}}$ & $50.94 \pm 2.35^{\mathrm{a}}$ & $47.21 \pm 3.33^{\mathrm{a}}$ & $50.42 \pm 3.81^{\mathrm{a}}$ \\
\hline
\end{tabular}

\section{Overview Of The Sequencing Data}

The total number of raw reads obtained by sequencing the 12 samples was $125.21 \mathrm{G}$ and the number of clean reads was $120.87 \mathrm{G}$ with an average proportion of $96.11 \%$ (94.28-97.59\%; Table S2). The transcriptome data were compared to the reference genome (Sscrofa11.1) and the proportion of mapped reads was $>95 \%$ (95.37-96.66\%), where an average of $85.8 \%$ reads were mapped within exons, $9.2 \%$ mapped to introns, and $5.0 \%$ mapped to intergenic regions (Fig. 1A).

After quantifying the expression of protein-coding genes using FPKM analysis, we compared the expression patterns of protein-coding genes in different samples. A total of 17,302 genes (FPKM $>0.05)$ were obtained in the LD muscle and back subcutaneous fat tissue of Dingyuan pigs, and 13081 genes were co-expressed in the four groups (Fig. 1B). The gene expression distributions of protein-coding genes were similar in all samples from different tissues (Fig. 1C).

\section{Identification And Functional Analysis Of Differentially Expressed Genes}

A total of 191 genes were differentially expressed between the HBF and LBF groups (Table S3), of which 63 were upregulated and 128 were downregulated in HBF (Fig. 2A). The 191 DEGs were enriched in 83 significantly enriched $\mathrm{GO}$ terms, which mainly involved ion binding, metal ion binding, cation binding, cell differentiation, small molecule metabolic processes, and other related biological processes (Fig. 2B, Table S4A). KEGG enrichment analysis showed that the 21 significantly enriched pathways were primarily involved in metabolism, fatty acid degradation, fatty acid metabolism, notch signaling pathway, and hypertrophic cardiomyopathy, among others (Fig. 2C). Moreover, fatty acid biosynthesis and the AMPactivated protein kinase (AMPK), PPAR, MAPK, PI3K-Akt, adipocytokine, and FoxO signaling pathwaysall related to lipogenesis-were also enriched (Table S4b). 
A total of 85 DEGs were identified between the HIMF and LIMF groups, including 31 upregulated and 54 downregulated genes in HIMF (Fig. 3A, Table S5). The GO analysis identified 120 significantly enriched terms (Table S6a), of which the top 20 most enriched genes were mainly associated with catalytic activity, cell population proliferation, growth factor receptor binding, cytoskeleton organization, and cellular lipid metabolic process, among other functions (Fig. 3B). The results of KEGG pathway analysis showed that the DEGs were involved 81 pathways and 18 were significantly enriched (Fig. 3C, Table S6b). Among these, many were related to fat formation and metabolism, such as the FoxO, adipocytokine, PPAR, and AMPK signaling pathways.

\section{Comparison of DEGs from subcutaneous fat and the LD muscle}

To identify the genes that specifically regulate subcutaneous and intramuscular fat deposition, we compared the DEGs from the two tissues and found 3 overlapping DEGs-KRT80, PRKAG3, and SLC7A5. $P R K A G 3$ is considered a candidate gene involved in subcutaneous and intramuscular fat deposition.

We selected 22 DEGs with specific differences in subcutaneous fat as candidate genes, including genes related to fatty acid biosynthesis and degradation ( $F A S N, A C A D S B$, and $G C D H$ ), amino acid metabolism (ADHFE1, TKT, and ACAT1), propanoate metabolism (ECHDC1 and ACSS3), and carbon metabolism (ALDH1L1 and ALDH6A1), as well as 12 genes (AACS, SERPINE1, PPARD, UBD, UCP2, SERPINE1, FBP1, $C A 3, K L F 2$, PFKFB1, ACP5, PRG4) associated with fat cell differentiation, butanoate metabolism, the PPAR signaling pathway, regulation of gluconeogenesis, and glucose metabolism (Table 2). 
Table 2

Potential key candidate genes identified from the transcriptome. LD, longissimus dorsi; $\log _{2} \mathrm{FC}, \log _{2}$ fold change; FDR, false discovery rate.

\begin{tabular}{|c|c|c|c|c|c|}
\hline $\begin{array}{l}\text { Gene } \\
\text { name }\end{array}$ & $\begin{array}{l}\log _{2} \mathrm{FC} \text { in } \\
\text { subcutaneous } \\
\text { fat }\end{array}$ & $\begin{array}{l}\text { FDR in } \\
\text { subcutaneous } \\
\text { fat }\end{array}$ & $\begin{array}{l}\log _{2} \mathrm{FC} \\
\text { in the } \\
\text { LD } \\
\text { muscle }\end{array}$ & $\begin{array}{l}\text { FDR in } \\
\text { the LD } \\
\text { muscle }\end{array}$ & Gene function \\
\hline FASN & -2.96285 & 0.000001 & 0.47826 & 0.67607 & $\begin{array}{l}\text { Metabolic pathways, fatty } \\
\text { acid metabolism, AMPK } \\
\text { signaling pathway, insulin } \\
\text { signaling pathway, fatty acid } \\
\text { biosynthesis }\end{array}$ \\
\hline CA3 & -2.26031 & 0.004719 & -0.84586 & 0.57883 & $\begin{array}{l}\text { Metabolic pathways, } \\
\text { nitrogen metabolism, } \\
\text { cellular anatomical entity, } \\
\text { cellular process, metabolic } \\
\text { process, binding, } \\
\text { intracellular }\end{array}$ \\
\hline TKT & -1.05613 & 0.000520 & 0.21110 & 0.97801 & $\begin{array}{l}\text { Metabolic pathways, carbon } \\
\text { metabolism, amino acid } \\
\text { biosynthesis, pentose } \\
\text { phosphate pathway, alpha- } \\
\text { amino acid metabolic } \\
\text { process, sulfur compound } \\
\text { metabolic process, positive } \\
\text { regulation of potassium ion } \\
\text { transport }\end{array}$ \\
\hline KLF2 & 1.41477 & 0.000055 & 0.16371 & 0.99102 & White fat cell differentiation \\
\hline ACAT1 & -1.01960 & 0.000071 & -0.43082 & 0.95335 & $\begin{array}{l}\text { Reproductive structure } \\
\text { development, sulfur amino } \\
\text { acid biosynthetic process, } \\
\text { metabolic pathways, valine, } \\
\text { leucine, and isoleucine } \\
\text { degradation, propanoate } \\
\text { metabolism, carbon } \\
\text { metabolism, pyruvate } \\
\text { metabolism }\end{array}$ \\
\hline ALDH1L1 & -2.35834 & 8.61E-08 & -0.90571 & 0.91253 & $\begin{array}{l}\text { One carbon pool by folate, } \\
\text { One Carbon Metabolism, } \\
\text { Folate Metabolism }\end{array}$ \\
\hline ECHDC1 & -1.43454 & 5.01E-09 & -0.02139 & 0.99586 & $\begin{array}{l}\text { Metabolic pathways, } \\
\text { propanoate metabolism, } \\
\text { metabolic process, catalytic } \\
\text { activity }\end{array}$ \\
\hline
\end{tabular}




\begin{tabular}{|c|c|c|c|c|c|}
\hline $\begin{array}{l}\text { Gene } \\
\text { name }\end{array}$ & $\begin{array}{l}\log _{2} \mathrm{FC} \text { in } \\
\text { subcutaneous } \\
\text { fat }\end{array}$ & $\begin{array}{l}\text { FDR in } \\
\text { subcutaneous } \\
\text { fat }\end{array}$ & $\begin{array}{l}\log _{2} F C \\
\text { in the } \\
\text { LD } \\
\text { muscle }\end{array}$ & $\begin{array}{l}\text { FDR in } \\
\text { the LD } \\
\text { muscle }\end{array}$ & Gene function \\
\hline ADHFE1 & -1.85280 & 2.19E-08 & -0.50819 & 0.92831 & $\begin{array}{l}\text { Reproduction, alpha-amino } \\
\text { acid metabolic process, } \\
\text { sulfur compound metabolic } \\
\text { process, reproductive } \\
\text { structure development, } \\
\text { regulation of muscle system } \\
\text { process, citric acid cycle, } \\
\text { respiratory electron } \\
\text { transport, pyruvate } \\
\text { metabolism }\end{array}$ \\
\hline ACADSB & -1.18737 & 0.000048 & -0.29033 & 0.95987 & $\begin{array}{l}\text { Metabolic pathways, valine, } \\
\text { leucine, and isoleucine } \\
\text { degradation, fatty acid } \\
\text { degradation, fatty acid } \\
\text { metabolism }\end{array}$ \\
\hline ALDH6A1 & -1.17949 & 0.004352 & -0.79455 & 0.54191 & $\begin{array}{l}\text { Metabolic pathways, valine, } \\
\text { leucine, and isoleucine } \\
\text { degradation, propanoate } \\
\text { metabolism, carbon } \\
\text { metabolism, inositol } \\
\text { phosphate metabolism, } \\
\text { beta-alanine metabolism }\end{array}$ \\
\hline AACS & -2.27971 & $2.28 \mathrm{E}-10$ & -0.68441 & 0.73266 & $\begin{array}{l}\text { Metabolic pathways, valine, } \\
\text { leucine, and isoleucine } \\
\text { degradation, butanoate } \\
\text { metabolism }\end{array}$ \\
\hline SERPINE1 & 1.63599 & 0.003084 & -0.99366 & 0.77249 & $\begin{array}{l}\text { Adipogenesis, blood clotting } \\
\text { cascade, complement and } \\
\text { coagulation cascades }\end{array}$ \\
\hline PPARD & 1.30507 & 0.000548 & -1.19111 & 0.23847 & $\begin{array}{l}\text { Pathways in cancer, PPAR } \\
\text { signaling pathway, acute } \\
\text { myeloid leukemia, Wnt } \\
\text { signaling pathway, ion } \\
\text { binding, metal ion binding, } \\
\text { small molecule metabolic } \\
\text { process }\end{array}$ \\
\hline UBD & 1.02161 & 0.001181 & 0.07256 & 0.99490 & $\begin{array}{l}\text { Proteasome binding, protein } \\
\text { ubiquitination, positive } \\
\text { regulation of apoptotic } \\
\text { process }\end{array}$ \\
\hline
\end{tabular}




\begin{tabular}{|c|c|c|c|c|c|}
\hline $\begin{array}{l}\text { Gene } \\
\text { name }\end{array}$ & $\begin{array}{l}\log _{2} \mathrm{FC} \text { in } \\
\text { subcutaneous } \\
\text { fat }\end{array}$ & $\begin{array}{l}\text { FDR in } \\
\text { subcutaneous } \\
\text { fat }\end{array}$ & $\begin{array}{l}\log _{2} \mathrm{FC} \\
\text { in the } \\
\text { LD } \\
\text { muscle }\end{array}$ & $\begin{array}{l}\text { FDR in } \\
\text { the LD } \\
\text { muscle }\end{array}$ & Gene function \\
\hline UCP2 & 1.44530 & 0.002745 & 0.27950 & 0.97436 & $\begin{array}{l}\text { Anatomical structure } \\
\text { morphogenesis, reproductive } \\
\text { structure development, } \\
\text { cardiac muscle tissue } \\
\text { development, cell junction } \\
\text { organization, muscle cell } \\
\text { development }\end{array}$ \\
\hline FBP1 & -1.78347 & 0.004800 & -3.33968 & / & $\begin{array}{l}\text { Negative regulation of } \\
\text { glycolytic process, } \\
\text { regulation of } \\
\text { gluconeogenesis, fructose 6- } \\
\text { phosphate metabolic } \\
\text { process, negative regulation } \\
\text { of cell growth }\end{array}$ \\
\hline ACSS3 & -1.19635 & 0.009090 & -0.73653 & 0.62802 & $\begin{array}{l}\text { Metabolic pathways, } \\
\text { propanoate metabolism }\end{array}$ \\
\hline PFKFB1 & -3.26636 & $6.02 \mathrm{E}-06$ & 0.90415 & 0.26914 & $\begin{array}{l}\text { Regulation of glycolysis by } \\
\text { fructose } 2,6-\text { bisphosphate } \\
\text { metabolism, metabolism, } \\
\text { glycolysis, glucose } \\
\text { metabolism, focal adhesion- } \\
\text { PI3K-Akt-mTOR-signaling } \\
\text { pathway, carbohydrate } \\
\text { metabolism }\end{array}$ \\
\hline $\mathrm{GCDH}$ & -1.16760 & 2.19E-08 & -0.19610 & 0.98930 & $\begin{array}{l}\text { Metabolic pathways, fatty } \\
\text { acid degradation, lysine } \\
\text { degradation, tryptophan } \\
\text { metabolism }\end{array}$ \\
\hline ACP5 & 2.07205 & 0.007519 & 0.92431 & 0.95335 & $\begin{array}{l}\text { Metabolism, metabolism of } \\
\text { water-soluble vitamins and } \\
\text { cofactors, NAD } \\
\text { phosphorylation and } \\
\text { dephosphorylation }\end{array}$ \\
\hline PRG4 & 3.61705 & 0.525778 & -1.38560 & 1.94832 & $\begin{array}{l}\text { Phospholipase-C Pathway, } \\
\text { ERK signaling, integrin } \\
\text { pathway, MAPK signaling }\end{array}$ \\
\hline LPL & 1.00349 & 0.002139 & 1.15750 & 0.10242 & $\begin{array}{l}\text { Fatty acid } \beta \text {-oxidation, } \\
\text { adipogenesis, PPAR } \\
\text { signaling pathway, } \\
\text { lipoprotein metabolism, } \\
\text { triacylglyceride synthesis }\end{array}$ \\
\hline
\end{tabular}




\begin{tabular}{|c|c|c|c|c|c|}
\hline $\begin{array}{l}\text { Gene } \\
\text { name }\end{array}$ & $\begin{array}{l}\log _{2} \mathrm{FC} \text { in } \\
\text { subcutaneous } \\
\text { fat }\end{array}$ & $\begin{array}{l}\text { FDR in } \\
\text { subcutaneous } \\
\text { fat }\end{array}$ & $\begin{array}{l}\log _{2} F C \\
\text { in the } \\
L D \\
\text { muscle }\end{array}$ & $\begin{array}{l}\text { FDR in } \\
\text { the LD } \\
\text { muscle }\end{array}$ & Gene function \\
\hline PRKAG3 & -2.73175 & 0.007801 & 1.87501 & 0.00149 & $\begin{array}{l}\text { Longevity regulating } \\
\text { pathway, AMPK signaling } \\
\text { pathway, apelin signaling } \\
\text { pathway, insulin signaling } \\
\text { pathway, oxytocin signaling } \\
\text { pathway, non-alcoholic fatty } \\
\text { liver disease, tight junction }\end{array}$ \\
\hline RETREG1 & -0.73548 & 0.403354 & -2.72111 & 0.00000 & $\begin{array}{l}\text { nucleolus, endoplasmic } \\
\text { reticulum, Golgi apparatus }\end{array}$ \\
\hline PRKAG2 & -0.50079 & 0.068174 & -2.57251 & 0.00403 & $\begin{array}{l}\text { Vitamin digestion and } \\
\text { absorption, thermogenesis, } \\
\text { lipid metabolism }\end{array}$ \\
\hline SMPDL3A & 0.20620 & 0.868544 & -3.52920 & 0.00000 & $\begin{array}{l}\text { Vitamin digestion and } \\
\text { absorption, sphingomyelin } \\
\text { phosphodiesterase activity, } \\
\text { sphingomyelin metabolic } \\
\text { process, cellular lipid } \\
\text { metabolic process, } \\
\text { membrane lipid catabolic } \\
\text { process, sphingolipid } \\
\text { catabolic process, } \\
\text { phospholipid catabolic } \\
\text { process }\end{array}$ \\
\hline IRS2 & -0.03815 & 0.971924 & -1.78695 & 0.00030 & $\begin{array}{l}\text { Adipogenesis genes, focal } \\
\text { adhesion-PI3K-Akt-mTOR- } \\
\text { signaling pathway, } \\
\text { erythropoietin activates } \\
\text { phosphoinositide-3-kinase, } \\
\text { IL-13 signaling pathway, } \\
\text { signaling by type } 1 \text { insulin- } \\
\text { like growth factor } 1 \text { receptor }\end{array}$ \\
\hline $\mathrm{BDH} 1$ & -0.05789 & 0.975117 & -1.92965 & 0.00878 & $\begin{array}{l}\text { Vitamin digestion and } \\
\text { absorption, butanoate } \\
\text { metabolism, metabolic } \\
\text { pathways, ketone body } \\
\text { catabolism, lipid } \\
\text { metabolism }\end{array}$ \\
\hline PPARA & -0.58082 & 0.502387 & -1.59100 & 0.00067 & $\begin{array}{l}\text { Vitamin digestion and } \\
\text { absorption, cAMP signaling } \\
\text { pathway, Hepatitis C }\end{array}$ \\
\hline GK & 0.06790 & 0.966532 & -1.98564 & 0.00415 & $\begin{array}{l}\text { Vitamin digestion and } \\
\text { absorption, glycerolipid } \\
\text { metabolism, metabolic } \\
\text { pathways }\end{array}$ \\
\hline
\end{tabular}




\begin{tabular}{|llllll|}
\hline $\begin{array}{l}\text { Gene } \\
\text { name }\end{array}$ & $\begin{array}{l}\log _{2} \mathrm{FC} \text { in } \\
\text { subcutaneous } \\
\text { fat }\end{array}$ & $\begin{array}{l}\text { FDR in } \\
\text { subcutaneous } \\
\text { fat }\end{array}$ & $\begin{array}{l}\log _{2} \mathrm{FC} \\
\text { in the } \\
\text { LD } \\
\text { muscle }\end{array}$ & $\begin{array}{l}\text { FDR in } \\
\text { the LD } \\
\text { muscle }\end{array}$ & Gene function \\
\hline LEP & 0.71676 & 0.328614 & 3.16540 & 0.00023 & $\begin{array}{l}\text { AMP-activated protein } \\
\text { kinase Signaling, } \\
\text { adipocytokine signaling } \\
\text { pathway, peptide hormone } \\
\text { metabolism, cytokine- } \\
\text { cytokine receptor interaction }\end{array}$ \\
\hline
\end{tabular}

In the LD muscle, following GO and KEGG analysis, we selected 8 genes mainly involved in fat metabolism-related pathways as candidate genes for the specific regulation of intramuscular fat deposition. These included the fat synthesis gene IRS2 (insulin receptor substrate 2), the transcription factor PPARA (peroxisome proliferator activated receptor alpha), the adipocyte secretory product $L E P$ (leptin), genes related to fatty acid $\beta$-oxidation, the lipid metabolism-related gene RETREG1 (reticulophagy regulator 1), GK (glycerol kinase), $B D H 1$ (3-hydroxybutyrate dehydrogenase 1), SMPDL3A (sphingomyelin phosphodiesterase acid like $3 \mathrm{~A}$ ), and PRKAG2 (protein kinase AMP-activated non-catalytic subunit gamma 2). The expression levels of these candidate genes in the two tissues are shown in Fig. 4.

\section{Protein Identification And Quantification}

A total of 29,519 peptides were obtained from the MS analysis of the subcutaneous fat tissue, and 4,099 proteins were identified. In contrast, 14,619 peptides and 2,178 proteins were obtained from the LD muscle. Among the identified proteins, $78.3 \%$ of those in the subcutaneous fat tissue (Fig. S1A) and $82.3 \%$ of those in the LD muscle (Fig. S1B) were represented by 1-10 peptides, and the molecular weight of the proteins mainly ranged from 10 to $80 \mathrm{kDa}$ (Fig. S1C, Fig. S1D). The coefficient of variation of $>90 \%$ of the four groups of replicates was less than $30 \%$, indicating that our experimental samples had good biological reproducibility (Fig. S2).

\section{Screening And Functional Classification Of Daps}

In total, 62 DAPs were identified between the HBF and LBF groups, of which 22 were upregulated and 40 were downregulated (Fig. S3, Table S7a). The heatmap of the DAPs showed that the expression levels had good repeatability within each group (Fig. S4). The 62 DAPs were enriched in 69 G0 terms (Table S7b). Approximately half of the 20 most significantly enriched GO terms were related to lipid and fatty acid metabolism, including the fatty acid catabolic process, fatty acid oxidation, fatty acid metabolic process, lipid oxidation, lipid metabolic process, cellular lipid metabolic process, and lipid catabolic process, among others (Fig. 5A, Table S7b). The enriched pathways indicated by KEGG analysis mainly included fatty acid degradation, fatty acid metabolism, and the PPAR signaling pathway and metabolic pathways (Fig. 5B, Table S7c). The 8 DAPs (ACAA2, ACAT1, ACOX1, CPT1A, ACSL4, SDHD, and IDH3A) were mainly associated with these pathways. In addition, 4 genes-MMUT, PCCB, HMGCL, and ALDH6A1 
-were involved in the synthesis and degradation of ketone bodies and propanoate metabolism, and are also considered important candidate proteins (Table 3). 
Table 3

Potential key candidate proteins identified from the proteome. LBF, low backfat thickness; HBF, high backfat thickness; HIMF, high intramuscular fat; LIMF, low intramuscular fat.

\begin{tabular}{|c|c|c|c|c|c|}
\hline $\begin{array}{l}\text { Protein } \\
\text { name }\end{array}$ & $\begin{array}{l}\text { Fold change } \\
\text { (HBF/LBF) in } \\
\text { the proteome }\end{array}$ & $P$-value & $\begin{array}{l}\text { Fold change } \\
\text { (HIMF/LIMF) } \\
\text { in the } \\
\text { proteome }\end{array}$ & $P$-value & Functional analysis \\
\hline ACAA2 & 0.81683 & 0.02263 & 0.84136 & 0.36089 & $\begin{array}{l}\text { Propanoate metabolism, fatty } \\
\text { acid degradation, fatty acid } \\
\text { metabolism }\end{array}$ \\
\hline ACAT1 & 0.70871 & 0.04268 & 0.95727 & 0.87357 & $\begin{array}{l}\text { Propanoate metabolism, fatty } \\
\text { acid degradation, fatty acid } \\
\text { metabolism, synthesis and } \\
\text { degradation of ketone bodies }\end{array}$ \\
\hline ALDH6A1 & 0.81354 & 0.00886 & 0.81433 & 0.08507 & $\begin{array}{l}\text { Valine, leucine, and isoleucine } \\
\text { degradation, propanoate } \\
\text { metabolism, carbon } \\
\text { metabolism, beta-alanine } \\
\text { metabolism, metabolic } \\
\text { pathways }\end{array}$ \\
\hline ACOX1 & 0.80644 & 0.02469 & / & / & $\begin{array}{l}\text { Propanoate metabolism, fatty } \\
\text { acid degradation, fatty acid } \\
\text { metabolism, PPAR signaling } \\
\text { pathway }\end{array}$ \\
\hline РCCB & 0.78891 & 0.04731 & 0.92308 & 0.41421 & Propanoate metabolism \\
\hline MMUT & 0.73611 & 0.01595 & 0.93050 & 0.34846 & Propanoate metabolism \\
\hline IDH3A & 0.83206 & 0.00272 & 0.97174 & 0.79603 & $\begin{array}{l}\text { Carbon metabolism, } \\
\text { metabolic pathways, citric } \\
\text { acid cycle }\end{array}$ \\
\hline HMGCL & 0.78701 & 0.04835 & l & / & $\begin{array}{l}\text { Valine, leucine, and isoleucine } \\
\text { degradation, synthesis and } \\
\text { degradation of ketone bodies, } \\
\text { peroxisome, metabolic } \\
\text { pathways, butanoate } \\
\text { metabolism }\end{array}$ \\
\hline CPT1A & 1.37812 & 0.03484 & / & / & $\begin{array}{l}\text { Fatty acid degradation, fatty } \\
\text { acid metabolism, PPAR } \\
\text { signaling pathway, } \\
\text { adipocytokine signaling } \\
\text { pathway, thermogenesis }\end{array}$ \\
\hline SDHD & 0.77096 & 0.00692 & 0 & 0 & $\begin{array}{l}\text { Carbon metabolism, } \\
\text { metabolic pathways, citric } \\
\text { acid cycle, thermogenesis, } \\
\text { Alzheimer's disease }\end{array}$ \\
\hline
\end{tabular}




\begin{tabular}{|llllll|}
\hline $\begin{array}{l}\text { Protein } \\
\text { name }\end{array}$ & $\begin{array}{l}\text { Fold change } \\
\text { (HBF/LBF) in } \\
\text { the proteome }\end{array}$ & $P$-value & $\begin{array}{l}\text { Fold change } \\
\text { (HIMF/LIMF) } \\
\text { in the } \\
\text { proteome }\end{array}$ & $P$-value & Functional analysis \\
\hline ACSL4 & 1.20345 & 0.00644 & $/$ & $/$ & $\begin{array}{l}\text { Fatty acid degradation, fatty } \\
\text { acid metabolism, peroxisome, } \\
\text { metabolic pathways, PPAR } \\
\text { signaling pathway, } \\
\text { adipocytokine signaling } \\
\text { pathway }\end{array}$ \\
\hline
\end{tabular}

Twelve DAPs were found in the HIMF vs. LIMF groups, of which 4 were upregulated and 8 were downregulated (Table S8a). The biological processes associated with the DAPs included developmental processes, multicellular organismal processes, protein modification processes, cellular processes, biological regulation, metabolic processes, and other biological processes (Table S8b). In total, 14 signal pathways enriched by KEGG analysis (Table S8c), including the PI3K-Akt signaling pathway, regulation of the actin cytoskeleton, and metabolic pathways, among others. TRIM55 (tripartite motif containing 55; involved in cellular protein metabolism), PTGR2 (prostaglandin reductase 2; involved in prostaglandin metabolism), and UBD (ubiquitin D; involved in cellular protein metabolism) were considered to be a candidate gene for IMF deposition.

\section{Integrated Analysis Of Transcriptomic And Proteomic Data}

On integrating the 191 DEGs and 62 DAPs from comparisons of the HBF and LBF groups, we found 8 overlapping genes (ACAT1, ALDH6A1, ISLR, HSDL2, MCCC2, IVD, EPHX1, and PRG4). Moreover, all 8 genes showed the same expression trends in terms of mRNA and protein. The PRG4 gene was highly expressed in the HBF group, whereas the remaining 7 genes were low in HBF. Based on the DEGs and DAPs, a protein-protein interaction (PPI) network was established for the Sus scrofa database using the STRING v.10.0 online software (Fig. S5). We found that IVD, ALDH6A1, ACSS3, ECDH1, ACADSB, ACAA2, ACSS1, HSDL2, HMGCL, PCCB, MCCC2, PCCA, AACS, ACOX1, and ACAT1 played pivotal roles in the network.

For the LD muscle tissue, among the 85 DEGs and 12 DAPs, only one overlapping gene-LMOD2 (leiomodin 2)-was found. This gene is mainly involved in the processes of myofibril assembly and muscle structure development. The PPI network diagram shows that the DEGs and DAPs in the LD muscle group were mainly centered on the INS gene (Fig. S6) and interacted with actin-related proteins and regulators such as ACTR10, ACTR1A, PFN2, and ENAH, whereas those in the other group interacted with insulin- and insulin receptor-related genes and substrate genes such as INSR, IRS1, and fat regulatory genes $L E P$ and PPARA.

\section{Verification Of Degs And Daps}


We selected ten DEGs (ALDH1L1, FASN, LPL, IGFBP5, ACAT1, INSR, RETREG1, FZD10, PPARA, PRKAG3) to test the validity of the RNA-Seq and TMT-based proteomic results. For this, we performed RT-qPCR using RNA samples from fat and muscle tissues of Dingyuan pigs. The expression levels of these genes in each group are shown in Fig. S1. The 10 genes selected were differentially expressed among the groups, and the mRNA and protein expression trends of these 10 genes were concordant with those obtained by RT-qPCR. Further, fold changes of all 10 genes in the qRT-PCR and RNA-Seq showed the same trends (Fig. S2). The results indicated that the DEGs identified by RNA-Seq and the DAPs identified by TMT-based proteomics were reliable and efficient.

\section{Discussion}

Dingyuan pigs have high subcutaneous and intramuscular fat contents. The population is a native breed that has not undergone strong artificial selection, and contains individuals with divergent backfat thickness and intramuscular fat content. Comparing gene expression between individuals with divergent traits in the same population can reduce noise due to different genetic backgrounds. The clean reads obtained from the transcriptome mapped to $>94.2 \%$ of the genome, which is higher than the value reported in previous studies on the pig backfat and LD muscle transcriptome [9, 13-15]. The current results show that our transcriptome sequencing results are of high quality. Through integrated transcriptomic and proteomic analysis, we found 8 overlapping genes in the subcutaneous fat group and only 1 overlapping gene in the LD muscle group. Due to the existence of multiple post-transcriptional regulatory mechanisms, similar results have been reported in many studies [16-19]. This prompted us to analyze integrated transcriptomic and proteomic data to better identify functional genes and their regulatory pathways.

\section{Comparison Of Enrichment Function Characterization}

Adipose tissue is not only an important energy store but is also essential for normal carbohydrate and lipid homeostasis. In addition to storing energy, white adipose tissue can also secrete enzymes and transcription factors, and are important secretory organs in the body [20,21]. On comparing the KEGG pathways enriched by DEGs in the subcutaneous fat and the LD muscle, we found that the hypertrophic cardiomyopathy signaling pathway was the only one common to both groups. Most of the DEG-enriched pathways identified in subcutaneous fat were metabolic pathways, including the metabolic processes of various amino acids, esters, fatty acids, and other intermediate products in glucose metabolism. The DEGs in the LD muscle group participated in a wide range of signaling pathways, including insulin, ketone body synthesis and degradation, longevity, and some disease-related pathways. Our results are consistent with those of another study which reported that pathways related to adipogenesis, lipolysis, glycolysis, and fatty acid oxidation were significantly downregulated in intramuscular adipocytes compared those in adipocytes from other locations $[22,23]$. Previous studies have also reported the differences in the regulatory mechanisms of subcutaneous and intramuscular fat production [24]. 
We separately analyzed the signaling pathways involved in the genes upregulated and downregulated in the HBF group and found that the highly expressed DEGs in the LBF group were mainly involved in fatty acid degradation and metabolism, pyruvate metabolism, pentose phosphate pathway, and other pathways related to lipid metabolism. The DEGs more highly expressed in the HBF group had functional categories related to inflammation and immunity, such as viral myocarditis, lipid and atherosclerosis, the AGE-RAGE signaling pathway in diabetic complications, and natural killer cell-mediated cytotoxicity. Human obesity is known to be associated with many diseases, including diabetes, dyslipidemia, cardiovascular disease, and cancer [25]. As an animal model for studying human obesity, pigs exhibit obesity complications similar to those of humans [26]. Therefore, it is particularly important to identify the different mechanisms of regulation of intramuscular and subcutaneous fat such that IMF content can be increased without increasing backfat deposition.

\section{Candidate genes affecting the production of subcutaneous adipose tissue and their regulatory changes}

Among the 8 genes identified in the subcutaneous fat group, MCCC2 and IVD are involved in leucine metabolism. Based on their functions, the genes ACAT1, ALDH6A1, and PRG4 were selected as candidate proteins involved in regulating subcutaneous fat deposition in pigs. In addition to these common genes, we also identified proteins involved in fatty acid metabolism (ACAA2, ACOX1, CPT1A, and ACSL4), propionate metabolism (ALDH6A1, PCCB, MMUT), ketone body metabolism (HMGCL), and the citric acid cycle (IDH3A); the genes coding these proteins may be candidate genes for regulating subcutaneous fat in pigs. Our transcriptome proteome had very few overlapping genes, and the results indicate that there is post-transcriptional regulation of fat deposition in Dingyuan pigs. In addition, due to the limitations of sequencing technology, the number of proteins identified by the proteome was far lower than that in the transcriptome. Moreover, the number of proteins detected in the two tissues was very different, and many proteins were not detected. Therefore, we believe that DEGs that exist only in the transcriptome can also be used as important candidate genes.

In our study, PRKAG3 was the only DEG found to participate in fat metabolism in the transcriptome of both tissues. The PRKAG3 gene encodes the AMPK regulatory subunit $ү 3$ [27]. AMPK activity is associated with increased glucose uptake and fatty acid oxidation, as well as inhibition of glycogen synthase activity and fatty acid synthesis [28]. Two missense mutations in the pig PRKAG3 gene-A595G (Ile199Val) and G154A (Gly52Ser)-are related to the IMF content, water-holding, and meat quality of pigs [29], and the AMPKY3R200Q mutation results in a lack of AMP dependence and elevated basal activity of AMPK [28]. The current research on pig PRKAG3 is focused on IMF. Based on the FPKM value of the transcriptome, we found that PRKAG3 expression is high in muscle tissue and very low in fat tissue; therefore, the role of this gene in pig backfat deposition remains to be verified.

Our results showed that in the HBF and HIMF groups, most of the candidate genes that regulate the biological process of adipogenesis were downregulated. Lipoprotein lipase (LPL) is one of the key enzymes involved in lipid metabolism. It is the rate-limiting enzyme for the catabolism of triglycerides and can remove TG-rich, very low-density lipoproteins and chylomicrons from the blood [30,31]. Fatty 
acid synthase (FASN) is a key enzyme in the de novo fatty acid synthesis pathway and cell substrate energy metabolism [32]. Acetoacetyl-CoA synthetase (AACS) is an enzyme that provides acetyl units for the biosynthesis of cholesterol and fatty acids [33]. AACS gene expression in white adipose tissue is lower in Zucker fatty rats than in lean rats; however, in high-fat diet induced obese rats, the expression of this gene is increased [34]. ALDH1L1 and ALDH6A1 belong to the aldehyde dehydrogenases family. The $A L D H 6 A 1$ gene is involved in the metabolism of a variety of aliphatic and aromatic aldehydes produced by various endogenous and exogenous precursors, and is also an important candidate gene that affects drip loss [35]. Moreover, ALDH1L1 is an enzyme that metabolizes folate [36]. At present, there are almost no reports on the relationship between these two genes and fat deposition. However, based on the various metabolic pathways they participate in and their differential expression in the HBF and LBF groups, we speculate that they may play a role in the subcutaneous fat deposition process in pigs.

ADHFE1 expression is highly enriched in adipose tissue and other highly metabolically active tissues, and its expression is closely related to the phenotype of mature adipocytes in vivo and in vitro [37]. The candidate genes related to subcutaneous adipogenesis that were upregulated in the HBF group included $K L F 2, A C P 5$, SERPINE1, PPARD, UBD, and UCP2. KLF2 inhibits fat formation by negatively regulating adipocyte differentiation, but does not affect the commitment of multipotent stem cells to the preadipocytic lineage [38]. ACP5, which is associated with excessive fat deposition and the development of atherosclerosis in pigs [39]. SERPINE1 (also known as PAI-1) is mainly produced in white adipose tissue and increases the cardiovascular risk in obese and diabetic patients, whereas its deficiency can prevent obesity and metabolic dysfunction $[40,41]$. The peroxisome proliferator-activated receptor delta gene $(P P A R D)$ is a key regulator of lipid metabolism, and its haplotype is associated with pig backfat thickness [42]. Studies in C2C12 myoblasts have shown that overexpression of PPARD inhibits myotube formation and enhances adipocyte differentiation [43]. In mice, knockout of the UBD gene prevents the development of age-related obesity while prolonging lifespan and vitality [44]. UCP2 participates in the oxidation of mitochondrial substrates and plays an important role in metabolic pathways $[45,46]$.

Studies have reported that some SNPs in UCP2 are related to obesity and type 2 diabetes [47-49]. Among these differential genes, genes that are positively related to adipogenesis were down-regulated (e.g., $F A S M$ ), and some were upregulated (e.g., $A C P 5$ ), indicating that fat metabolism in the body is a dynamic and balanced process.

\section{Candidate genes affecting the production of IMF and their regulatory changes}

In the transcriptome of the IMF group, we found many enriched pathways related to lipid metabolism. Based on these pathways, we identified genes that may regulate intramuscular fat deposition. RETREG1, also known as $P F A M 134 B$, promotes the accumulation of subcutaneous fat in pigs by increasing the mRNA levels of PPARY, FAS, and ACC, and reducing the levels of ATGL and HSL [50]. PRKAG2 is an important regulator of cardiac metabolism [51]; an SNP of $P R K A G 2$ is associated with insulin sensitivity and is essential for obesity, triglycerides, and HDL cholesterol [52]. SMPDL3A-a recently identified phosphodiesterase-plays a role in cholesterol and fat metabolism by regulating the liver X-receptor [53]. The insulin receptor substrate 2 (IRS2) is the first downstream effector of the insulin receptor. Studies 
have found that the absence of IRS2 in myeloid cells improves glucose homeostasis and enhances resistance to metabolic dysfunction induced by a high-fat diet [54]. In addition, the proteins LEP [55], GK [56], and PPARA [57]-reported to be associated with obesity or adipose-related biological processeswere also included in our results.

The purpose of our experiment was to identify genes that specifically regulate subcutaneous and intramuscular fat in pig with extreme backfat and IMF. Interestingly, some of the DEGs and DAPs identified in the backfat groups in this study-namely, IGFBP5, PTGR2, PPARD, GK, LEP, PPARA, and UBDhave also been reported as candidate genes regulating intramuscular fat in other studies. For instance, $U B D$ expression was upregulated in our HBF transcriptome and in the proteome of the HIMF group. Studies have shown that $U B D$ has a positive regulatory effect on intramuscular and subcutaneous fat, and that inhibition of $U B D$ in intramuscular and subcutaneous adipocytes results in the inhibition of cell proliferation and lipid droplet production [58].

From our results, it is worth mentioning that the RETREG1 gene was downregulated in the HIMF group. Although it has been suggested that this gene has an inhibitory effect on intramuscular fat deposition in Dingyuan pigs, studies have shown that it also promotes subcutaneous fat deposition. The opposing roles of genes in the two types of adipose tissue are beneficial for the selection of high-quality pigs, and their functions can be explored through further studies.

\section{Conclusions}

Excluding the genes that co-regulate intramuscular and subcutaneous fat, we suggest that in Dingyuan pigs, the FASN, LPL, AACS, TKT, ALDH6A1, ALDH1L1, KLF2, ACP5, SERPINE1, UCP2, FBP1, ACSS3, PFKFB1, ECHDC1, ACADSB, GCDH, ACAA2, ACOX1, CPT1A, ACSL4, ALDH6A1, PCCB, MMUT, HMGCL, IDH3A, PRG4, and CTSL genes may regulate subcutaneous fat deposition, whereas PRKAG2, SMPDL3A, IRS2, BDH1, TRIM55, ACSL4, and CTP1A may regulate intramuscular fat deposition.

\section{Materials And Methods}

\section{Animals and samples}

The Dingyuan pigs were raised in the Ankang Agriculture and Animal Husbandry Company, Dingyuan County, Anhui Province, with consistent feeding conditions. Over 200 unmated sows that were 10 months old and showed normal growth were selected and their body weight and live backfat thickness were measured using a platform scale and a B-ultrasound instrument (SSD-500V, ALOKA, Japan). Based on the measurements, 12 individuals with similar body weights were selected such that six had extremely high live backfat thickness and six had extremely low live backfat thickness. The pigs were slaughtered to measure the carcass weight, backfat thickness, lean meat percentage, and meat quality traits. The LD muscle and back subcutaneous fat tissues were collected, immediately frozen in liquid nitrogen, and stored at $-80^{\circ} \mathrm{C}$. Animals were reared and handled in accordance with the Guide for the Care and Use of 
Laboratory Animals in China. All experimental guidelines were approved by the Committee on the Ethics of Animal Experiments of China Agricultural University (permit number: SKLAB-2012-04-07).

\section{Measurement Of Intramuscular Fat}

A fresh sample of the LD muscle tissue was cut into pieces, the connective tissue and fascia were removed, and the remaining tissue was homogenized. The LD muscle samples were then dried to a constant weight in an oven and the dried samples were ground into powder. The Soxhlet extraction method was used to determine IMF content in muscle tissue.

Based on backfat thickness and IMF content, subcutaneous fat samples were divided into high backfat thickness $(H B F, n=3)$ and low backfat thickness $(L B F, n=3)$, and $L D$ muscle samples were divided into the high intramuscular fat $(H I M F, n=3)$ and low intramuscular fat $(L I M F, n=3)$ groups.

\section{Library Preparation And Sequencing}

Total RNA was extracted from the LD muscle and back subcutaneous fat tissues using the TRIzol method. RNase-free DNase was added to total RNA to remove DNA contamination. The integrity of RNA was checked by $1.2 \%$ agarose gel electrophoresis and the quality and amount of total RNA were determined using a Nanodrop 2000 instrument (Thermo Fisher Scientific, Waltham, MA, USA). The RNA integrity number (RIN) values of all samples were above 7 , and $2.5 \mu \mathrm{g}$ of total RNA was used to construct the cDNA library. The Illumina NovaSeq6000 platform (Illumina, San Diego, CA, USA) was used for transcriptome sequencing, and the sequencing read length was paired-end $150 \mathrm{bp}$. From the raw data obtained by sequencing, we filtered out low-quality sequences (Q-value $<19)$, sequences contaminated by linkers, and reads with an $\mathrm{N}$ content $>5 \%$ to obtain clean data.

Clean reads were mapped to the reference pig (Sus scrofa) genome version scrofa.Sscrofa11.1 (ftp://ftp.ensembl.org/pub/release-99/fasta/sus_scrofa/dna/Sus_scrofa.Sscrofa11.1.dna.toplevel.fa) using the HISAT2 (V2.0.5) software for alignment. We used the Cufflinks (V2.2.1) software to calculate fragments per kilobase million mapped reads (FPKM) values to represent gene expression levels. Genes with an average FPKM value $>0.05$ (including all individuals in one group) were defined as being expressed for that group, and those with an average FPKM value $<0.05$ were defined as being nonexpressed in the group. Here, we used DESeq2 (V1.25.9) to analyze the differences between the four groups of Dingyuan pig samples. Differentially expressed genes (DEGs) were defined as those with false discovery rate $(F D R)<0.01$ and absolute $\log _{2}$ of the fold change $\left(\left|\log _{2} F C\right|\right) \geq 1$.

\section{Protein Sample Preparation And Tmt Tag Labeling}

The samples used for the proteomic analyses were the same as those used for RNA-SEq. An appropriate amount of sample tissue was added to the protein lysis solution (Mammal Tissue Total Protein 
Extraction Kit AP0601-50, Invent Biotechnologies, Inc., Plymouth, MN, USA). After sonication, the samples were placed on ice for $20 \mathrm{~min}$, centrifuged at $10,000 \times \mathrm{g}$ at $4^{\circ} \mathrm{C}$ for $30 \mathrm{~min}$, transferred to a new tube, and stored at $-80^{\circ} \mathrm{C}$. Protein concentrations of the samples were determined using a BCA kit (Thermo Fisher Scientific), and protein quality was detected by SDS-PAGE. The peptides were labeled with TMT isobaric tags (Thermo Fisher Scientific) at room temperature for $1 \mathrm{~h}$.

The TMT-labeled samples were fractionated using a high-pH peptide fractionation protocol. Each sample was fractionated into 60 fractions using a step gradient of $0-95 \%$ acetonitrile. Next, the 60 fractions were pooled into 10 fractions in a non-contiguous manner. Each sample was separated using a high-

performance liquid chromatography (HPLC) system. The chromatographic column was balanced with $95 \%$ solution $\mathrm{A}(98 \% \mathrm{H} 2 \mathrm{O}, \mathrm{pH} 10)$, loaded onto the mass spectrometer pre-column using the autosampler, and then separated by an analytical column. The separated samples were analyzed using a Q Exactive Plus mass spectrometer (Thermo Fisher Scientific).

After mass spectrometry analysis, the Proteome Discoverer 2.4 software (Thermo Fisher Scientific) was used to process all the original files against the Sus_scrofa.Sscrofa11.1.pep.all.fa database. The peptide confidence was set to a high level (q-value $<0.01$ ) for peptide filtering. Quantification of experimental bias was set to normalize the total peptide amount. FC $\geq 1.2, \mathrm{FC} \leq 0.833$, and $P$-value $\leq 0.05$ were set as thresholds for identifying differentially abundant proteins (DAPs).

\section{Functional Annotation Of Degs And Daps}

Gene ontology (GO) and Kyoto Encyclopedia of Genes and Genomes (KEGG) pathway enrichment analysis of the DEGs was performed using the KOBAS 3.0 enrichment analysis tool (https://kobas.cbi.pku.edu.cn/anno_iden.php). Functional analysis of DAPs was conducted using the UniProt ftp database and the KEGG PATHWAY database. The Pathway Maps tool was used to enrich the pathways, and P-values were calculated using R software based on a hypergeometric distribution, with the default database being used as the background.

\section{Validation Of Important Candidate Genes}

To confirm the DEGs identified in RNA-Seq and the DAPs identified in TMT-based proteomics, qRT-PCR was performed on 10 genes to measure their expression levels in different groups. The primer sequences used are listed in Table S1. Quantitative real-time PCR (qPCR) reactions were performed using the SYBR Green qPCR SuperMix (Transgen, Beijing, China) using a Bio-Rad CFX96 System (Bio-Rad, Hercules, CA, USA) with a reaction volume of $20 \mu \mathrm{L}$. A cDNA pool of all samples was used for calibration and the experiment was performed in triplicate for each sample. Gene expression levels were calculated using the $2-\Delta \Delta \mathrm{Ct}$ method.

\section{Statistical analysis}


The differences in slaughter traits and gene expression levels were analyzed using the t-test in SPSS (version 21.0; IBM Corp. Released 2012. IBM SPSS Statistics for Windows, Armonk, NY, USA). Graphs were prepared using GraphPad Prism (version 7), and data are presented as the mean \pm standard error.

\section{Abbreviations}

DAP, differentially abundant protein; DEG, differentially expressed gene; FDR, false discovery rate; FPKM, fragments per kilobase million mapped reads; GO, gene ontology; HBF, high backfat thickness group; HIMF, high intramuscular fat group; IMF, intramuscular fat; KEGG, Kyoto Encyclopedia of Genes and Genomes; LBF, low backfat thickness group; LD, longissimus dorsi; LIMF, low intramuscular fat group; $\log _{2} \mathrm{FC}, \log _{2}$ fold change; qPCR, quantitative real-time PCR; TMT, tandem mass tags.

\section{Declarations}

\section{Ethics approval and consent to participate}

All animal work was conducted following the guidelines for the care and use of experimental animals. The Animal Welfare Committee of the State Key Laboratory for Agro-Biotechnology of the China Agricultural University approved all procedures for animal care (approval number, SKLAB-2012-04-07). The study was carried out in compliance with the ARRIVE guidelines.

\section{Consent for publication}

Not applicable.

\section{Availability of data and material}

All RNA-Seq data were deposited in the Gene Expression Omnibus under accession number GSE179457 (https://www.ncbi.nlm.nih.gov/geo/query/acc.cgi?acc=GSE179457). The mass spectrometry proteomics data have been deposited to the ProteomeXchange Consortium via the PRIDE partner repository with the dataset identifier PXD027061. The datasets supporting the conclusions of this article are included within the article and its additional files.

\section{Competing interests}

The authors declare no conflict of interest.

\section{Funding}

This work was supported by the National Natural Science Foundation of China (32060736), the Yunnan Science and Technology Project (No. 22018FG001-003), and Central Government Guides Local Science and Technology (No. YDZX20195400004426). 
P.Z., and H.Z. designed the research; P.Z., Y.Z., H.Z., Y.W., and Q.L. collected samples, extracted RNAs, and performed qRT-PCR verification experiments; P.Z. performed most of the bioinformatics studies; P.Z., H.Z., and B.Z. wrote and revised the manuscript; and all authors reviewed the manuscript. The authors read and approved the final manuscript.

\section{Acknowledgements}

We thanks Annoroad (Beijing, China) and Beijing Bangfei Bioscience \&Technology Co., Ltd (Beijing, China) for the sequencing services and bioinformatic analysis.

\section{References}

1. Yang SL, Wang ZG, Liu B, Zhang GX, Zhao SH, Yu M, Fan B, Li MH, Xiong TA, Li K: Genetic variation and relationships of eighteen Chinese indigenous pig breeds. Genetics Selection Evolution 2003, 35(6):657-671.

2. Dai FW, Feng DY, Cao QY, Ye H, Zhang CM, Xia WG, Zuo JJ: Developmental differences in carcass, meat quality and muscle fibre characteristics between the Landrace and a Chinese native pig. $S$ Afr $J$ Anim Sci 2009, 39(4):267-273.

3. Cameron ND, Warriss PD, Porter SJ, Enser MB: COMPARISON OF DUROC AND BRITISH LANDRACE PIGS FOR MEAT AND EATING QUALITY. Meat Science 1990, 27(3):227-247.

4. Wood JD, Kempster AJ, David PJ, Bovey M: Observations on Carcass and Meat Quality in Duroc, Landrace and Duroc X Landrace Pigs. Anim Prod 1987, 44:488-488.

5. Suzuki A, Kojima N, Ikeuchi Y, Ikarashi S, Moriyama N, Ishizuka T, Tokushige H: CARCASS COMPOSITION AND MEAT QUALITY OF CHINESE PUREBRED AND EUROPEAN X CHINESE CROSSBRED PIGS. Meat Science 1991, 29(1):31-41.

6. Zambonelli P, Gaffo E, Zappaterra M, Bortoluzzi S, Davoli R: Transcriptional profiling of subcutaneous adipose tissue in Italian Large White pigs divergent for backfat thickness. Anim Genet 2016, 47(3):306-323.

7. Wood JD, Enser M, Fisher AV, Nute GR, Sheard PR, Richardson RI, Hughes SI, Whittington FM: Fat deposition, fatty acid composition and meat quality: A review. Meat Science 2008, 78(4):343-358.

8. Newcom DW, Baas TJ, Schwab CR, Stalder KJ: Genetic and phenotypic relationships between individual subcutaneous backfat layers and percentage of longissimus intramuscular fat in Duroc swine. J Anim Sci 2005, 83(2):316-323.

9. Miao ZG, Wei PP, Khan MA, Zhang JZ, Guo LP, Liu DY, Zhang XJ, Bai YY, Wang S: Transcriptome analysis reveals differential gene expression in intramuscular adipose tissues of Jinhua and Landrace pigs. J Vet Med Sci 2018, 80(6):953-959.

10. Zhang YF, Sun YC, Wu ZZ, Xiong XW, Zhang JJ, Ma JW, Xiao SJ, Huang LS, Yang B: Subcutaneous and intramuscular fat transcriptomes show large differences in network organization and associations with adipose traits in pigs. Sci China Life Sci 2021. 
11. Canovas A, Quintanilla R, Amills M, Pena RN: Muscle transcriptomic profiles in pigs with divergent phenotypes for fatness traits. Bmc Genomics 2010, 11.

12. Thompson A, Schaefer J, Kuhn K, Kienle S, Schwarz J, Schmidt G, Neumann T, Johnstone RAW, Mohammed AKA, Hamon C: Tandem mass tags: A novel quantification strategy for comparative analysis of complex protein mixtures by MS/MS (vol 75, pg 1895, 2003). Anal Chem 2006, 78(12):4235-4235.

13. Xing K, Wang KJ, Ao H, Chen SK, Tan Z, Wang Y, Xitong Z, Yang T, Zhang FX, Liu YB et al: Comparative adipose transcriptome analysis digs out genes related to fat deposition in two pig breeds. Sci Rep-Uk 2019, 9.

14. Liu YZ, Yang XQ, Jing XY, He XM, Wang L, Liu Y, Liu D: Transcriptomics Analysis on Excellent Meat Quality Traits of Skeletal Muscles of the Chinese Indigenous Min Pig Compared with the Large White Breed. Int J Mol Sci 2018, 19(1).

15. Wu WJ, Zhang ZK, Chao Z, Li BJ, Li RY, Jiang AW, Kim KH, Liu HL: Transcriptome analysis reveals the genetic basis of skeletal muscle glycolytic potential based on a pig model. Gene 2021, 766.

16. Ma C, Wang WW, Wang YD, Sun Y, Kang L, Zhang Q, Jiang YL: TMT-labeled quantitative proteomic analyses on the longissimus dorsi to identify the proteins underlying intramuscular fat content in pigs. J Proteomics 2020, 213.

17. Ran LY, Xiang J, Zeng XX, Tang JL, Dong YT, Zhang F, Yu WF, Qi XL, Xiao Y, Zou J et al: Integrated transcriptomic and proteomic analysis indicated that neurotoxicity of rats with chronic fluorosis may be in mechanism involved in the changed cholinergic pathway and oxidative stress. $J$ Trace Elem Med Bio 2021, 64.

18. Zhang Y, Zheng XT, Zhang YW, Zhang HL, Zhang XY, Zhang H: Comparative transcriptomic and proteomic analyses provide insights into functional genes for hypoxic adaptation in embryos of Tibetan chickens. Sci Rep-Uk 2020, 10(1).

19. Dai WT, Chen Q, Wang QJ, White RR, Liu JX, Liu HY: Complementary transcriptomic and proteomic analyses reveal regulatory mechanisms of milk protein production in dairy cows consuming different forages. Sci Rep-Uk 2017, 7.

20. La Merrill M, Emond C, Kim MJ, Antignac JP, Le Bizec B, Clement K, Birnbaum LS, Barouki R: Toxicological Function of Adipose Tissue: Focus on Persistent Organic Pollutants. Environ Health Persp 2013, 121(2):162-169.

21. Pellegrinelli V, Carobbio S, Vidal-Puig A: Adipose tissue plasticity: how fat depots respond differently to pathophysiological cues. Diabetologia 2016, 59(6):1075-1088.

22. Gardan D, Gondret F, Van den Maagdenberg K, Buys N, De Smet S, Louveau I: Lipid metabolism and cellular features of skeletal muscle and subcutaneous adipose tissue in pigs differing in IGF-II genotype. Domest Anim Endocrin 2008, 34(1):45-53.

23. Wang SB, Zhou GX, Shu G, Wang LN, Zhu XT, Gao P, Xi QY, Zhang YL, Yuan L, Jiang QY: Glucose Utilization, Lipid Metabolism and BMP-Smad Signaling Pathway of Porcine Intramuscular 
Preadipocytes Compared with Subcutaneous Preadipocytes. Cell Physiol Biochem 2013, 31(6):981996.

24. Zhou GX, Wang SB, Wang ZG, Zhu XT, Shu G, Liao WY, Yu KF, Gao P, Xi QY, Wang XQ et al: Global comparison of gene expression profiles between intramuscular and subcutaneous adipocytes of neonatal landrace pig using microarray. Meat Science 2010, 86(2):440-450.

25. Sethi JK: Activatin' Human Adipose Progenitors in Obesity. Diabetes 2010, 59(10):2354-2357.

26. Renner S, Blutke A, Clauss S, Deeg CA, Kemter E, Merkus D, Wanke R, Wolf E: Porcine models for studying complications and organ crosstalk in diabetes mellitus. Cell Tissue Res 2020, 380(2):341378.

27. Roux M, Nizou A, Forestier L, Ouali A, Leveziel H, Amarger V: Characterization of the bovine PRKAG3 gene: structure, polymorphism, and alternative transcripts. Mamm Genome 2006, 17(1):83-92.

28. Barnes BR, Marklund S, Steiler TL, Walter M, Hjalm G, Amarger V, Mahlapuu M, Leng Y, Johansson C, Galuska $D$ et al: The 5 '-AMP-activated protein kinase gamma 3 isoform has a key role in carbohydrate and lipid metabolism in glycolytic skeletal muscle. J Biol Chem 2004, 279(37):3844138447.

29. Chen JF, Dai LH, Peng J, Li JL, Zheng R, Zuo B, Li FE, Liu M, Yue K, Lei MG et al: New evidence of alleles (V199I and G52S) at the PRKAG3 (RN) locus affecting pork meat quality. Asian Austral $J$ Anim 2008, 21(4):471-477.

30. Kersten S: Physiological regulation of lipoprotein lipase. Bba-Mol Cell Biol L 2014, 1841(7):919-933.

31. Ullrich NFE, Purnell JQ, Brunzell JD: Adipose tissue fatty acid composition in humans with lipoprotein lipase deficiency. J Invest Med 2001, 49(3):273-275.

32. Menendez JA, Lupu R: Fatty acid synthase and the lipogenic phenotype in cancer pathogenesis. Nat Rev Cancer 2007, 7(10):763-777.

33. Yamasaki M, Hasegawa S, Suzuki H, Hidai K, Saitoh Y, Fukui T: Acetoacetyl-CoA synthetase gene is abundant in rat adipose, and related with fatty acid synthesis in mature adipocytes. Biochem Bioph Res Co 2005, 335(1):215-219.

34. Yamasaki M, Hasegawa S, Kitani T, Hidai K, Fukui T: Differential effects of obesity on acetoacetylCoA synthetase gene in rat adipose tissues. Eur J Lipid Sci Tech 2007, 109(6):617-622.

35. Zhao $X$, Wang $C$, Wang $Y$, Zhou L, Hu H, Bai L, Wang J: Weighted gene co-expression network analysis reveals potential candidate genes affecting drip loss in pork. Anim Genet 2020, 51(6):855865.

36. Krupenko NI, Sharma J, Pediaditakis P, Fekry B, Helke KL, Du XX, Sumner S, Krupenko SA: Cytosolic 10-formyltetrahydrofolate dehydrogenase regulates glycine metabolism in mouse liver. Sci Rep-Uk $2019,9$.

37. Kim JY, Tillison KS, Zhou SL, Lee JH, Smas CM: Differentiation-dependent expression of Adhfe1 in adipogenesis. Arch Biochem Biophys 2007, 464(1):100-111. 
38. Wu JH, Srinivasan SV, Neumann JC, Lingrel JB: The KLF2 transcription factor does not affect the formation of preadipocytes but inhibits their differentiation into adipocytes. Biochemistry-Us 2005, 44(33):11098-11105.

39. Padilla J, Jenkins NT, Lee S, Zhang HR, Cui J, Zuidema MY, Zhang CH, Hill MA, Perfield JW, Ibdah JA et al: Vascular transcriptional alterations produced by juvenile obesity in Ossabaw swine. Physiol Genomics 2013, 45(11):434-446.

40. Ma LJ, Mao SL, Taylor KL, Kanjanabuch T, Guan YF, Zhang YH, Brown NJ, Swift LL, McGuinness OP, Wasserman $\mathrm{DH}$ et al: Prevention of obesity and insulin resistance in mice lacking plasminogen activator inhibitor 1. Diabetes 2004, 53(2):336-346.

41. Liu SJ, Li Y, Fan X, Li K, Xu CR, Zhang LP, Luo M, Wang LQ, Li R, Wu JB: Transplantation of adipose tissue lacking PAl-1 improves glucose tolerance and attenuates cardiac metabolic abnormalities in high-fat diet-induced obesity. Adipocyte 2020, 9(1):170-178.

42. Meidtner K, Schwarzenbacher H, Scharfe M, Severitt S, Blocker H, Fries R: Haplotypes of the porcine peroxisome proliferator-activated receptor delta gene are associated with backfat thickness. BmC Genet 2009, 10.

43. Yu YH, Wu SC, Cheng WTK, Mersmann HJ, Ding ST: Ectopic expression of porcine peroxisome proliferator-activated receptor delta regulates adipogenesis in mouse myoblasts. J Anim Sci 2008, 86(1):64-72.

44. Canaan A, DeFuria J, Perelman E, Schultz V, Seay M, Tuck D, Flavell RA, Snyder MP, Obin MS, Weissman SM: Extended lifespan and reduced adiposity in mice lacking the FAT10 gene. $P$ Natl Acad Sci USA 2014, 111(14):5313-5318.

45. van Dierendonck XAMH, Sancerni T, Alves-Guerra MC, Stienstra R: The role of uncoupling protein 2 in macrophages and its impact on obesity-induced adipose tissue inflammation and insulin resistance. J Biol Chem 2020, 295(51):17535-17548.

46. Vozza A, Parisi G, De Leonardis F, Lasorsa FM, Castegna A, Amorese D, Marmo R, Calcagnile VM, Palmieri L, Ricquier D et al: UCP2 transports C4 metabolites out of mitochondria, regulating glucose and glutamine oxidation. P Natl Acad Sci USA 2014, 111(3):960-965.

47. Oktavianthi S, Trimarsanto H, Febinia CA, Suastika K, Saraswati MR, Dwipayana P, Arindrarto W, Sudoyo H, Malik SG: Uncoupling protein 2 gene polymorphisms are associated with obesity. Cardiovasc Diabetol 2012, 11.

48. Csernus K, Pauler G, Erhardt E, Lanyi E, Molnar D: Uncoupling protein-2 gene polymorphisms are associated with obesity in Hungarian children. Acta Paediatr 2013, 102(5):e200-e204.

49. Oguzkan-Balci S, Col-Araz N, Nacak M, Araz M, Sabanci H, Balat A, Pehlivan S: Mitochondrial uncoupling protein 2 (UCP2) gene polymorphisms are associated with childhood obesity and related metabolic disorders. J Pediatr Endocr Met 2013, 26(3-4):277-283.

50. Yuan ZQ, Song DG, Wang YZ: The novel gene pFAM134B positively regulates fat deposition in the subcutaneous fat of Sus scrofa. Biochem Bioph Res Co 2014, 454(4):554-559. 
51. Torok RD, Austin SL, Phornphutkul C, Rotondo KM, Bali D, Tatum GH, Wechsler SB, Buckley AF, Kishnani PS: PRKAG2 mutations presenting in infancy. J Inherit Metab Dis 2017, 40(6):823-830.

52. Randrianarisoa E, Lehn-Stefan A, Krier J, Bohm A, Heni M, De Angelis MH, Fritsche A, Haring HU, Stefan N, Staiger H: AMPK Subunits Harbor Largely Nonoverlapping Genetic Determinants for Body Fat Mass, Glucose Metabolism, and Cholesterol Metabolism. J Clin Endocr Metab 2020, 105(1):1425.

53. Noto PB, Bukhtiyarov Y, Shi M, McKeever BM, McGeehan GM, Lala DS: Regulation of Sphingomyelin Phosphodiesterase Acid-Like 3A Gene (SMPDL3A) by Liver X Receptors. Mol Pharmacol 2012, 82(4):719-727.

54. Rached MT, Millership SJ, Pedroni SMA, Choudhury Al, Costa ASH, Hardy DG, Glegola JA, Irvine EE, Selman C, Woodberry MC et al: Deletion of myeloid IRS2 enhances adipose tissue sympathetic nerve function and limits obesity. Mol Metab 2019, 20:38-50.

55. Martinez-Sanchez N: There and Back Again: Leptin Actions in White Adipose Tissue. Int J Mol Sci 2020, 21(17).

56. Rahib L, MacLennan NK, Horvath S, Liao JC, Dipple KM: Glycerol kinase deficiency alters expression of genes involved in lipid metabolism, carbohydrate metabolism, and insulin signaling. Eur J Hum Genet 2007, 15(6):646-657.

57. Brocker CN, Patel DP, Velenosi TJ, Kim D, Yan TT, Yue J, Li GL, Krausz KW, Gonzalez FJ: Extrahepatic PPAR modulates fatty acid oxidation and attenuates fasting-induced hepatosteatosis in mice. $J$ Lipid Res 2018, 59(11):2140-2152.

58. Zhao C, Yao XP, Chen XC, Wu WJ, Xi FX, Yang GS, Yu TY: Knockdown of ubiquitin D inhibits adipogenesis during the differentiation of porcine intramuscular and subcutaneous preadipocytes. Cell Proliferat 2018, 51(2).

\section{Figures}




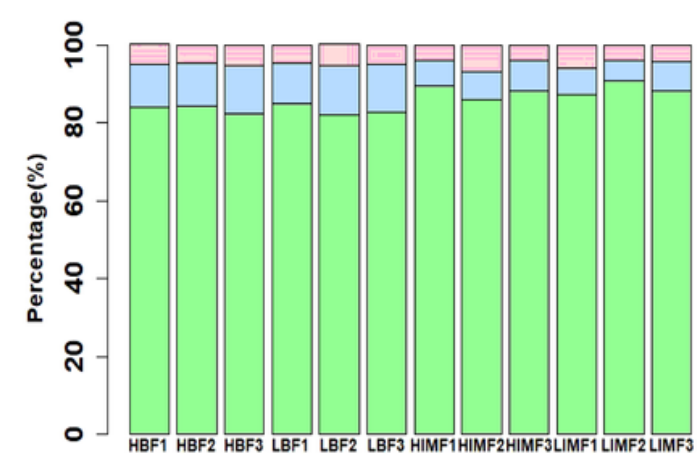

B

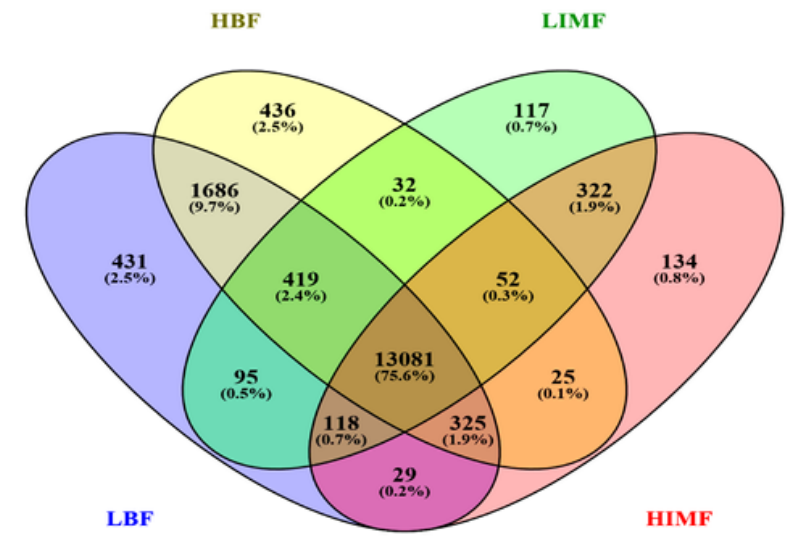

C

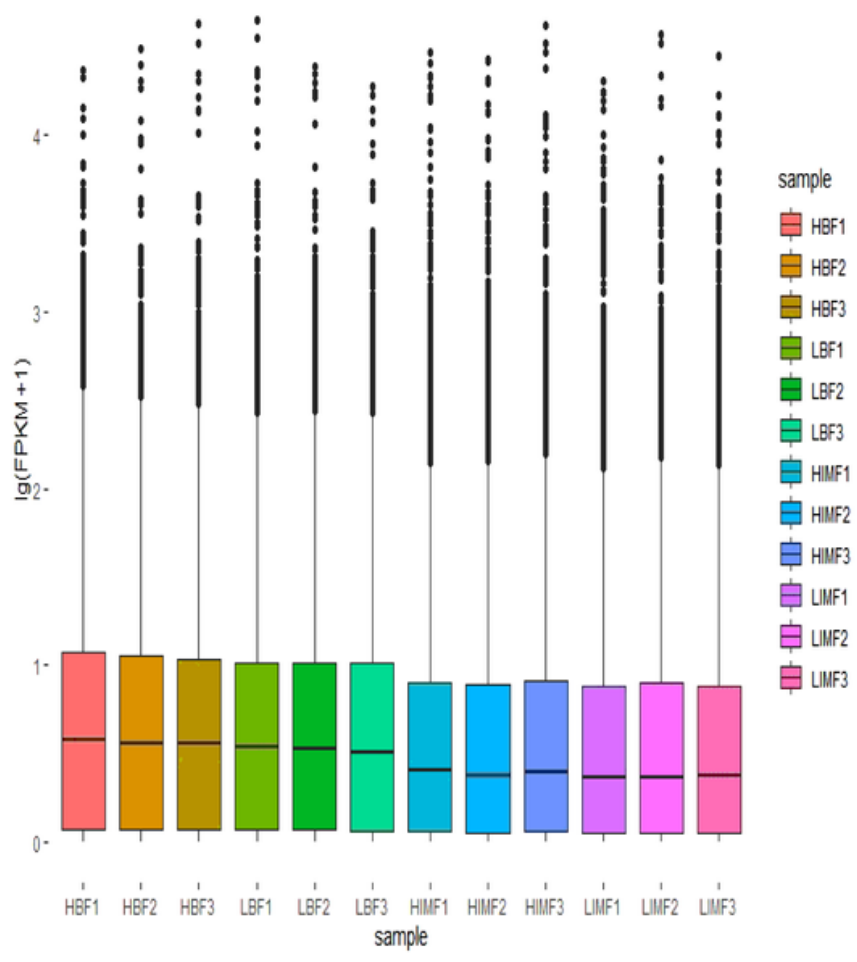

Figure 1

Comparison of sequencing reads and distribution of positively expressed genes. (A) The distribution of sequencing reads in the reference genome. The distribution of reads in the exons (green), introns (blue), and intergenic regions (pink) are shown. (B) Venn diagrams of positively expressed genes in the four groups of pigs: LBF, low backfat thickness; HBF, high backfat thickness; HIMF, high intramuscular fat; LIMF, low intramuscular fat. (C) Distributions of expression values of 12 samples. The boxplots show $\log 10($ FPKM +1$)$ values of each gene from the 6 sets of RNA-Seq data. The black lines in the boxes represent the medians. 


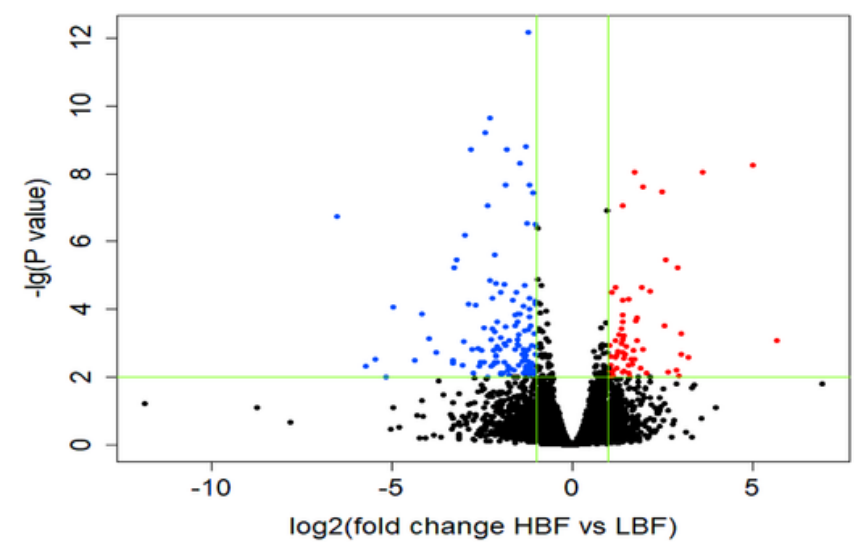

B

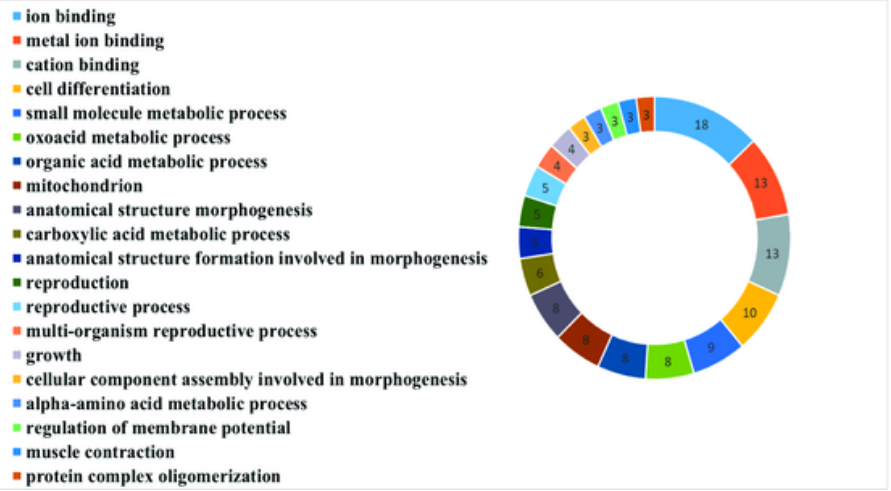

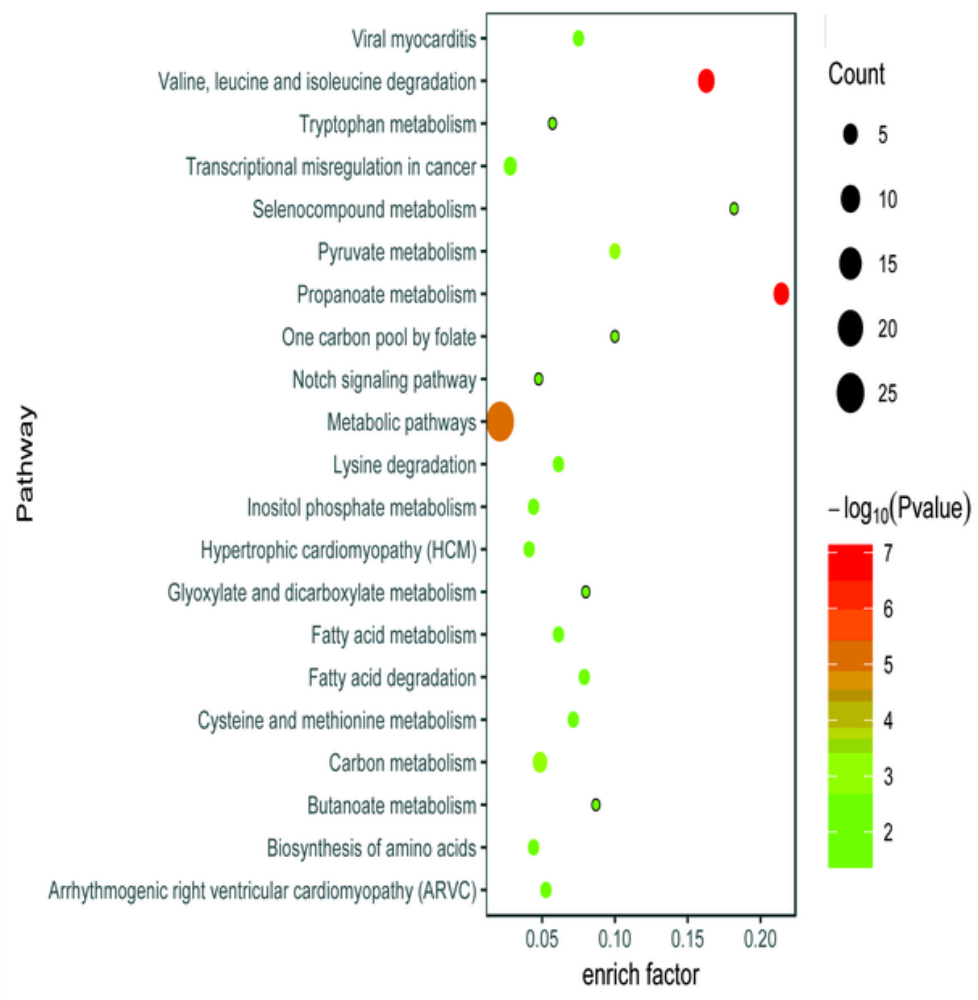

Figure 2

Identification and functional analysis of DEGs in the HBF and LBF groups. (A) Volcano plot of DEGs from samples of subcutaneous fat. The abscissa indicates log2FC, the ordinate indicates - $\lg$ (FDR) values, red dots indicate differential expression of upregulated genes, blue dots indicate differential expression of downregulated genes, and black dots indicate no differential expression. (B) GO enrichment analysis of DEGs between the HBF and LBF groups. (C) KEGG enrichment analysis of DEGs. The rich factor is the ratio of DEGs numbers annotated in this pathway term to the total gene numbers annotated in the same pathway term. Smaller P-values indicate higher significance. 


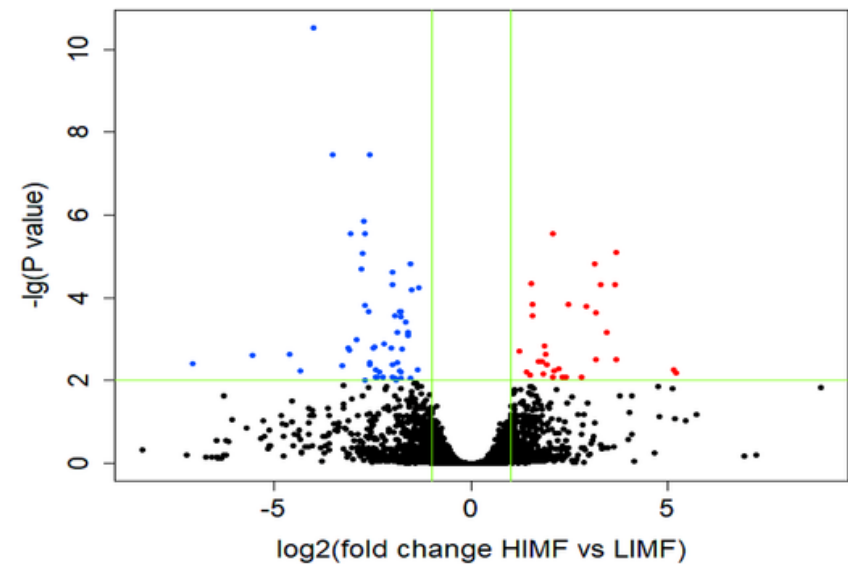

B

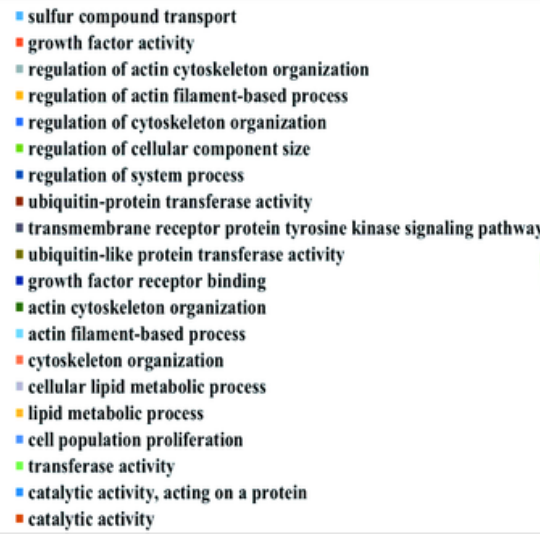

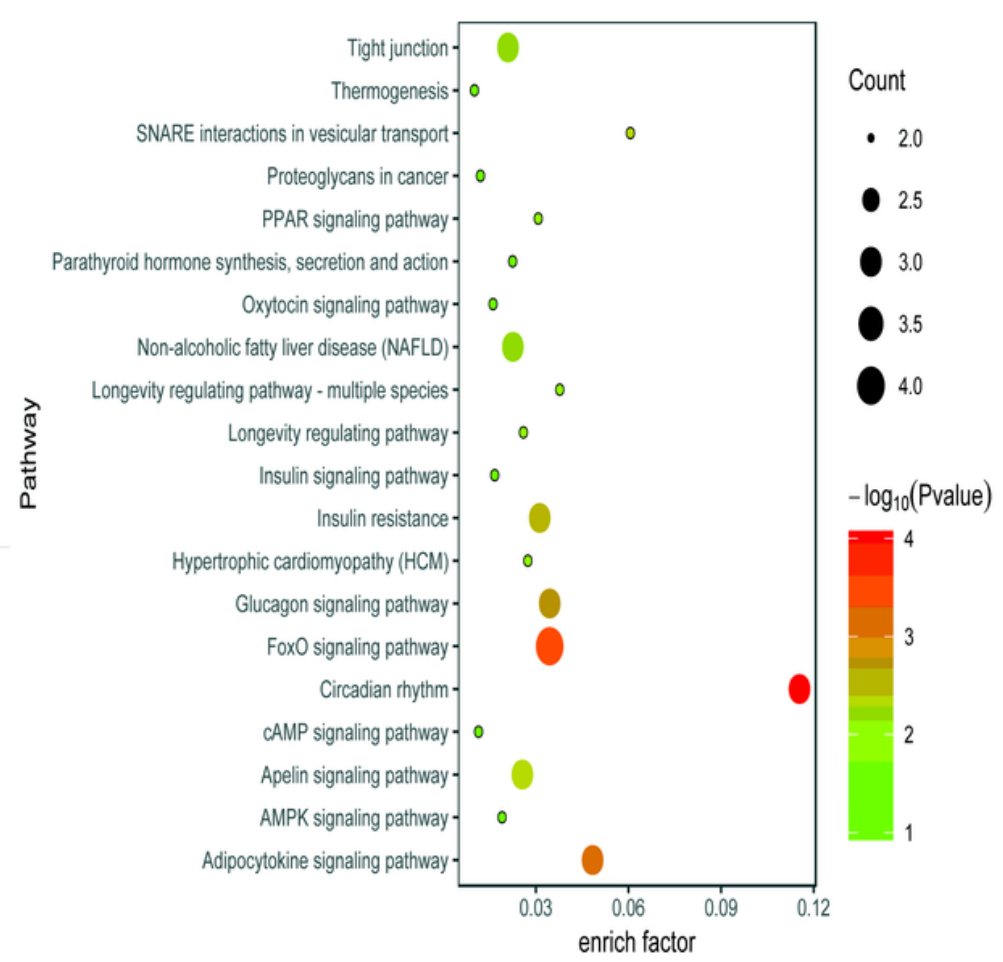

Figure 3

Identification and functional analysis of DEGs in the IMF group. (A) Volcano plot of DEGs from LD muscle samples. The abscissa indicates log2 fold change, the ordinate indicates -lg (FDR) values, red dots indicate differential expression of upregulated genes, blue dots indicate differential expression of downregulated genes, and black dots indicate no differential expression. (B) GO enrichment analysis of DEGs between the HIMF and LIMF groups. (C) KEGG enrichment analysis of DEGs. The enrich factor is the ratio of DEGs annotated in a pathway term to the total genes annotated in the same pathway term. Smaller P-values indicate higher significance. 


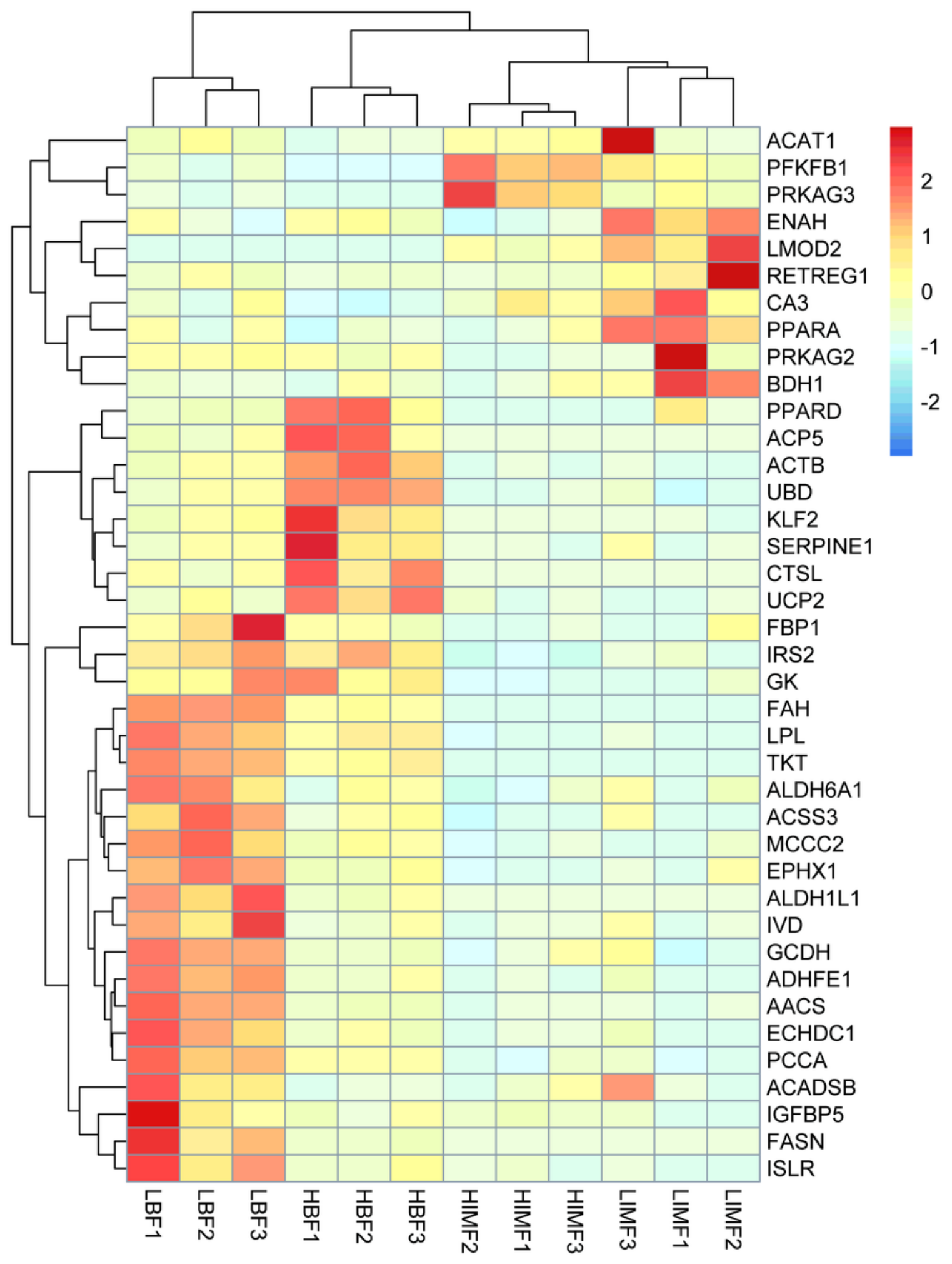

\section{Figure 4}

The expression levels of the candidate genes differentially expressed in the four groups of samples. Red colors represent high gene expression, blue colors represent low gene expression, and the color intensity changes with the FPKM value. 
A

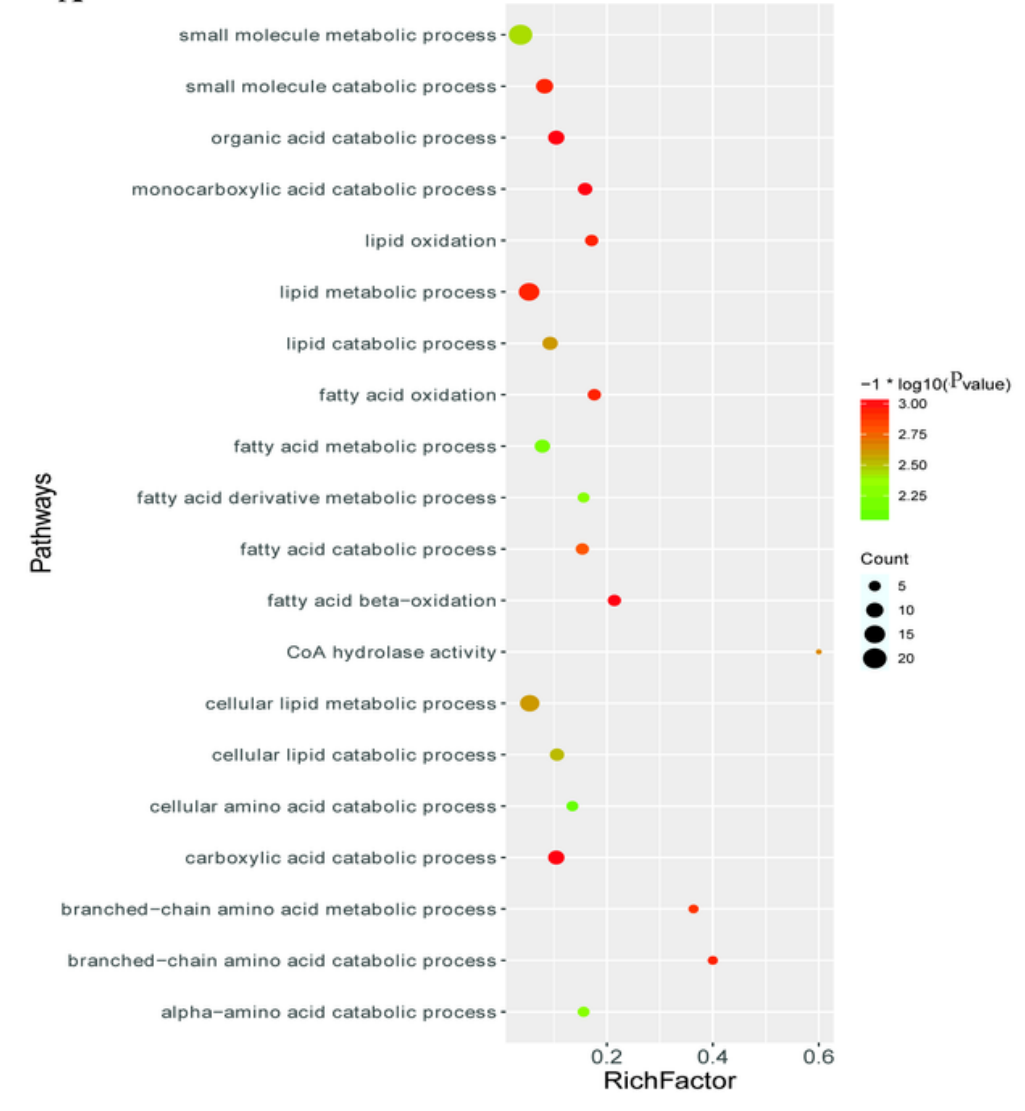

B

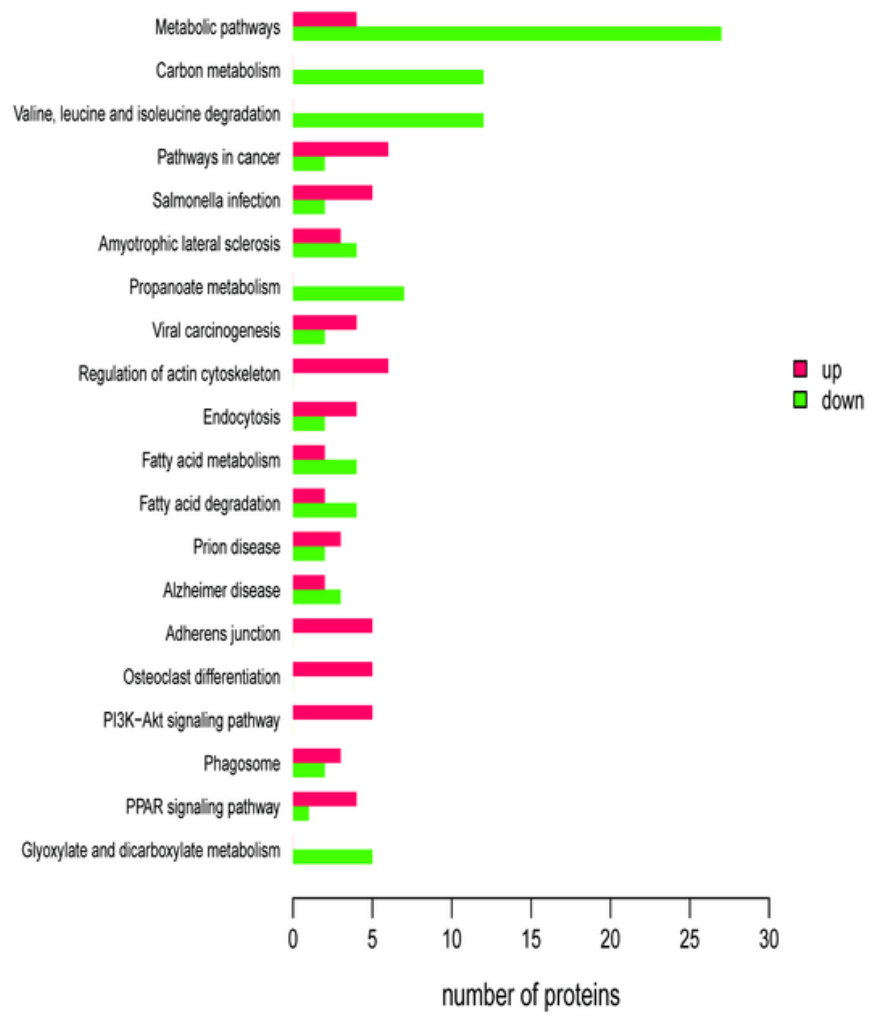

\section{Figure 5}

The GO and KEGG enrichment analysis of DAPs in subcutaneous fat. (A) GO enrichment analysis of DAPs between the HBF and LBF groups. The rich factor is the ratio of DEPs annotated in a pathway term to the total genes annotated in the same pathway term. Smaller P-values indicate higher significance. (B) KEGG enrichment analysis of DAPs. Red colors represent upregulated protein expression and green colors represent downregulated protein expression.

\section{Supplementary Files}

This is a list of supplementary files associated with this preprint. Click to download.

- Supplementaryfigures.pdf

- TableS1.xIsx

- Tablas2.xIsx

- TableS3.xIsx

- Tablas4.xlsx

- TableS5.xIsx

- TableS6.xIsx 
- Tables7.xIsx

- TableS8.xlsx 